JOURNAL OF SECURITY AND SUSTAINABILITY ISSUES

ISSN 2029-7017 print/ISSN 2029-7025 online

2020 March Volume 9 Number 3

https://doi.org/10.9770/jssi.2020.9.3(30)

Scopus

\title{
DIAGNOSTICS AND CONTROL OF SUSTAINABLE DEVELOPMENT OF REGIONS: BRANCH ASPECTS
}

\author{
Robert Hernández Martínez ${ }^{1}$, Svetlana Arutyunyan*2, Malvina Karabasheva ${ }^{3}$, Aigul Yesturliyeva ${ }^{4}$ \\ ${ }^{1}$ Universidad Iberoamericana, Lomas de Santa Fe, Delegación Álvaro Obregon, \\ México City, Prolongación Paseo de Reforma 880, Zip Code 01219 \\ ${ }^{2}$ Astrakhan State University, 414056, Tatisheva 20A, Astrakhan, Russian Federation \\ ${ }^{3}$ Financial University under the Government of the Russian Federation, Moscow, \\ Russian Federation, Leningradsky Prospekt, 49, 125993, Moscow, Russian Federation \\ ${ }^{4}$ Caspian state university named after Sh. Esenov, 130000, Building 1, micro-district 32, Aktau, Kazakhstan \\ E-mail:*2arutunyan1109@mail.ru (Corresponding author)
}

Received 13 January 2019; accepted 29 November 2019; published 30 March 2020

\begin{abstract}
The paper highlights theoretical and practical approaches to the development of a sustainable type of tourism in the region. The concept of "sustainable tourism development" has been clarified, the relationship between its components on the basis of the author's approach has been identified, which allows finding its most promising segment - international cruise tourism. The paper also discusses the optimization model for the development of international tourism in a region. Among the main segments that influence the development of cruise tourism in the region, sea, river and expeditionary cruises are considered. The profitability of the segments that affect the sustainable development of international cruise tourism in the region has been calculated.
\end{abstract}

Keywords: sustainable development; sustainable tourism; region; optimization model; international cruise tourism; profitability

Reference to this article should be made as follows: Martínez R.H., Arutyunyan S., Karabasheva M., Yesturliyeva A..2020. Diagnostics and control of sustainable development of regions: branch aspects. Journal of Security and Sustainability Issues, 9(3), $1065-1076$. https://doi.org/10.9770/jssi.2020.9.3(30)

JEL Classifications: Q01, R10, Z30, Z32, Z39.

Additional disciplines mathematics.

\section{Introduction}

Sustainable development of any region depends on development patters of its sectors of economy. Globalization of processes are closely related to expansion of tourism. There is a lot of attention to various facts of that sector in the recent scientific literature (e.g. Shevyakova et al., 2019; Singgalen et al., 2019; Zhylankozova, 2018; Chkalova et al., 2019 etc.). Concepts aimed at the possibility of the transition of the tourism sector and its subsectors to the path of sustainable development are becoming increasingly attractive. This is especially true for those countries where the development of tourism is based on the opportunity of creating long-term conditions and factors associated with the preservation of the natural resource potential, national, historical and cultural values of the country. This provision is in full accordance with the world trends of globalization in the field of tourism, the most important postulate of which is the preservation of natural systems, which in turn forms the conditions and directions for sustainable development.

Sustainable development of tourism has a multifaceted and ambiguous nature, based on planning and manage- 
ment, making it possible to protect the natural environment and cultural heritage and ensure economic benefits (Korableva et al., 2018; Yang, Černevičiūtè, 2017). As for the sustainable development of international tourism, and, in particular, tourism, integrated in a number of countries related by a commonality of interests in crossborder cooperation, due to cardinal differences in the tourism policy of the regions, it becomes necessary to take into account individual factors of influence that have a rather complex structure.

\section{Theoretical background}

At the end of the 1990s, the World Tourism Organization adopted the most important document entitled Agenda 21 for the Travel and Tourism Industry. It analyzes the effects of uncontrolled tourism growth aimed at quick profit, which has negative consequences in connection with damage to the environment and local communities and to the emergence of many other socio-economic problems. The document also noted that the tourism and travel sector had the potential needed to improve both environmental and socio-economic problems in those countries where there were tourism and appropriate culture (Pavlyshyn et al., 2019; Tarman, 2016; Fedulova et al., 2019). Moreover, the culture of intensive consumption must be reoriented to a culture of growth, leading to a balance of economic and environmental development parameters, intelligently distributing the benefits received (Kolupaev et al, 2018; Glotko et al., 2019; Voronkova et al., 2019; Prodanova et al., 2017).

In Agenda 21 for the Travel and Tourism Industry, the sustainable development of tourism is linked to meeting the current needs of tourists in the host regions while enhancing future opportunities (Rosland, 2001). Among the latest global trends in tourism development, a special place is occupied by the concept of sustainable tourism development. The need for the transition of the tourism sector to the principles of sustainable development in the modern conditions of globalization and informatization of society is obvious. Practice shows that the uncontrolled growth of tourism, which aims to quickly make a profit, often has negative consequences, since it damages the environment, the local community and destroys the very foundation on which the functioning and successful development of tourism rests (Vasilchenko, 2018; Kashirskaya et al., 2019; Dunets et al., 2019a,b).

The debate around the world about the concept of sustainable tourism development became a phenomenon of the 1990s. However, undoubtedly, the concept of sustainable development of tourism originates from the concept of sustainable development in general. The concept of sustainable development is multifaceted, multidimensional and ambiguous. Sustainable usually refers to development that satisfies the present needs without compromising the ability of future generations to meet their own needs (Ivanova et al., 2019). Thus, sustainable development takes into account longer-term prospects than a person usually does when making decisions and implies the need for management and planning (Goryushkina et al., 2019; Chernysheva et al., 2019; Akhmetshin et al., 2019).

\section{Methodology}

In order to identify how effective and sustainable each of the cruise tourism destinations for each of the countries of the Caspian region is, it is necessary to use the principles and conditions of optimization modeling, reflecting the relationship between generic (indicators of socio-economic development) and explicit variables (criteria). The construction of the optimization model was based on the statistical base of the Association of Sea Trade Ports (www.morport.com).

\section{Results and discussion}

Monitoring sustainable development of tourism should be comprehensive, since its subsystems are multifaceted, include a whole range of conditions and factors of economic, social and environmental nature, taking into account the political orientation. This approach to the study of tourism sustainability allowed the author to formulate the following classification, in which the political component that takes into account the interests of each country, i.e., cross-border cooperation of states belonging to a specific region, acts as a clarifying position for sustainable tourism (Fig. 1). 


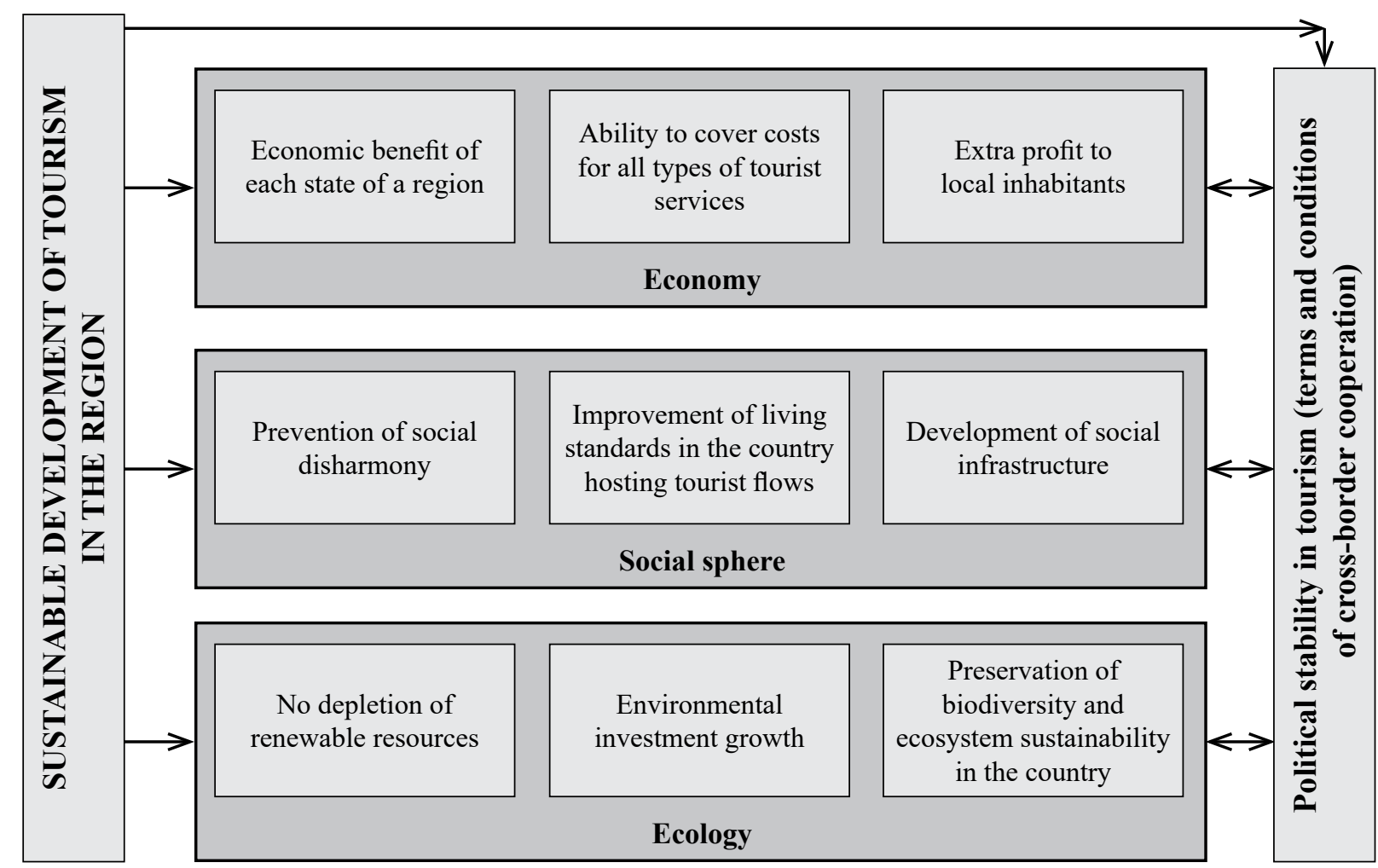

Figure 1. Sustainable development of tourism in the region

Source: authors' research

Here are the definitions of sustainable development of tourism in the region in terms of the sustainability of each of its components (Porohin, 2015; Urban, 2015; Prodanova et al., 2019; Prokhorova et al., 2016):

- economic sustainability is directly related to the presence for each country of economic benefits from the tourism sector, the ability to cover costs associated with real tourist flows, as well as providing real income to the local population of a host territory;

- socially sustainable tourism implies the ability of a country of a studied region to accept real and potential incoming flows of tourists, while avoiding the appearance of social disharmony;

- ecologically sustainable tourism has a stable natural resource base compatible with the load, the throughput potential of the ecosystem and its biodiversity (Korchevenkov and Aleksandrova, 2018);

- political stability implies stability in the development of international relations and cross-border cooperation, which are characterized by the International Council on the development of tourism in the region coordinated by the participants.

The formulation of tourism development programs in the region involves an economic assessment based on quantitative and qualitative parameters (criteria, indicators, indices) of its functioning. A similar assessment can be made based on the use of a set of models, and in particular optimization modeling, which makes it possible to choose the optimal method and direction of development with maximum results. In the most general form, the model for the implementation of sustainable tourism is depicted in Fig. 2.

Sustainable tourism development in the region implies economic, environmental, social and political sustainability. Each of the areas of sustainability has its own indicators that determine the development of tourism in each country in the region, and indicators that characterize the development of tourism activities of a local nature, being individual for each particular country. 


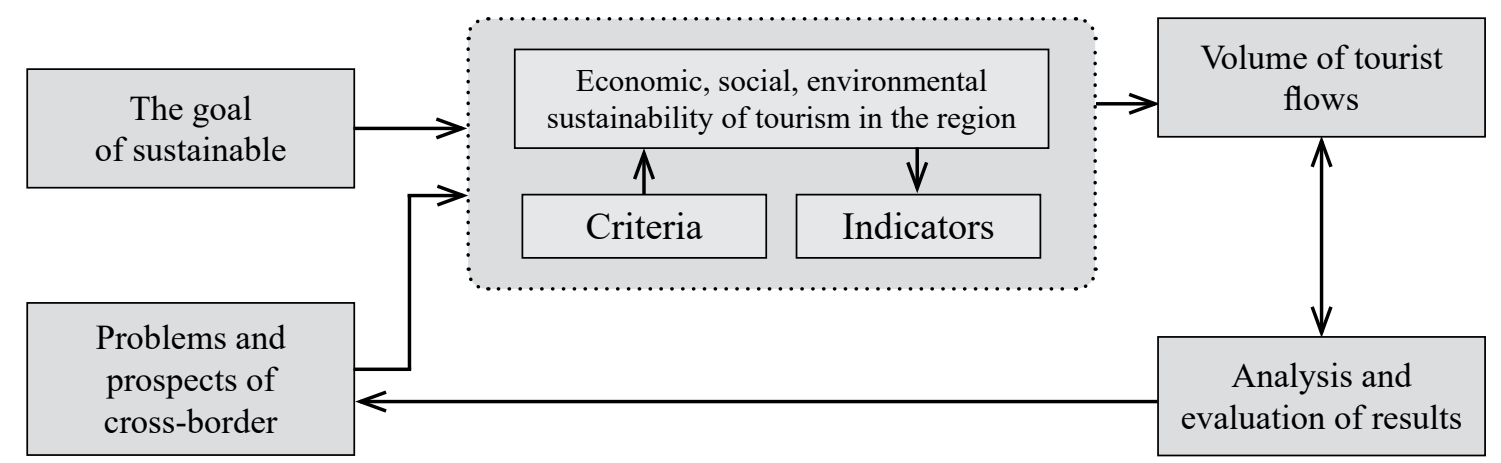

Figure 2. Implementation of sustainable development of tourism in the region

Source: authors' research

Sustainable forms of tourism are currently very diverse, it is only needed to maintain high levels of attractiveness for tourists in service, consistent with the international standards (Porokhin and Urban, 2015; Luzina et al., 2019).

To date, the Caspian region is one of the most important geopolitical centers, noticeable not only in political and business activity in the world but also in providing a high level of tourist attractiveness for its territories (Avanesyan, 2012). It should be noted that according to expert estimates of CNN Travel, another attractive region will soon appear on the world tourist map, which until recently remained inaccessible to traveling. After Russia, Azerbaijan, Kazakhstan, Turkmenistan, and Iran have agreed on the international status of the Caspian Sea, it will open up for mass tourism. In the early 1990s, the Caspian Sea was at the center of intense international negotiations. Five states shared the Caspian coastline: Russia in the west and northwest, Kazakhstan in the north, northeast, and east, Iran in the south, Azerbaijan in the southwest, Turkmenistan in the southeast. In 1996, the Caspian littoral states created a special working group, which was supposed to develop the Convention on the legal status of the Caspian Sea. After 27 years of negotiations, the states were able to come to a consensus and on August 12, 2018 in Aktau (Kazakhstan) they signed the Convention on the legal status of the Caspian Sea. On June 8, 2019, as part of the St. Petersburg International Economic Forum, a round table was held on "Russia in the Caspian Region. Prospects for the Development of International Trade". At the round table, among others, the topic of the development of cruise tourism on the Lower Volga and the Caspian Sea was discussed. Speaking at the meeting, the Minister of the Russian Federation for North Caucasus Affairs Sergey Chebotarev announced the construction of cruise terminals in Astrakhan and Derbent. The Moscow River Shipping Company, the largest owner of passenger tourist ships in Russia, is already preparing to master new routes: on May 24, 2019 at the Lotos shipyard in Astrakhan, the newest "Peter the Great" cruise ship of PV300VD project was launched, which will be able to make in the future two-week cruises along the Caspian Sea with call at the ports of Azerbaijan, Russia, Kazakhstan, Turkmenistan, and Iran.

So far, according to the published information, the new river-sea cruise ship is planned to be used on the inland waterways of the European part of the Russian Federation, in the Black and Azov Seas. The likely routes that the liner will serve are Moscow - St. Petersburg, Moscow - Sochi, Novorossiysk, and others. In the future, "Peter the Great" may enter the Moscow - Baku route. According to expert estimates, the demand for cruises in the Caspian Sea will be great, since there have been no cruises in this region yet. It is assumed that in the coming years all tickets will be sold out. As soon as the construction of "Peter the Great" liner is completed, the shipping company will immediately be ready to start cruises. Perhaps it will be already June 2020. It is also assumed that the liner will go along the route Baku - Sochi and Baku - Moscow and back. Moreover, according to the head of the shipping company, by the beginning of cruises in the Caspian Sea, border and customs formalities must be settled.

It is necessary, at least in Astrakhan, to introduce the procedure for passenger clearance, approximately the same as when clearing cargo ships, when the commission arrives onboard, checks the crew and then the ship 
can sail towards the border into the Caspian Sea (Kashirskaya et al. 2019). In addition, there are some difficulties with the port infrastructure in Makhachkala and Derbent, which today are not suitable for receiving cruise tourist ships. Therefore, it is planned to start cruise service without the Republic of Dagestan so far, departing from Astrakhan immediately to Kazakhstan. To attract foreign tourists, it is proposed to simplify visa procedures. The 2018 FIFA World Cup showed that with the facilitation in obtaining a visa, the number of people wishing to come to Russia is increasing. The same methods can be used, offering cruises to foreign guests. Accordingly, the Caspian region is a landmark in the development of cruise tourism.

The potential of the Caspian region is capable of giving a powerful impetus to the development of cruise tourism not only in the Caspian Sea but also throughout the Volga basin. This is an international route that will attract the Caspian states to the exchange of tourist flows. As far as it is known, the Caspian region includes the waters of the Caspian Sea and the coastal territories of Russia, Iran, Kazakhstan, Azerbaijan, and Turkmenistan. The Caspian region is still a territory of internal instability with a set of intricate ethnic, religious, territorial disputes and aggravation of interethnic conflicts, which, of course, leaves its mark on the development of the tourism sector. Nevertheless, sandy beaches, mineral springs with healing water and mud from coastal areas, which provide opportunities for active rest, treatment and recreation, are very attractive for tourists in terms of international travel. In the Caspian region, such types of tourism as cultural-cognitive (guided tours), beach, medical, recreational, ethnographic, mountain tourism, mountaineering, and, of course, cruises will make the most possible use of tourism resources and further strengthen the relationship between the Caspian Five countries.( Zakorin N.D.,2009) However, the development of the hospitality and leisure industry in general on the Caspian coast is quite behind the Black Sea coast. This is largely explained by the positioning of the Caspian Sea as a source of hydrocarbon production with the appropriate infrastructure. Nevertheless, significant progress has been made in the development of tourism in a number of countries in the Caspian region. In some countries, resort and recreation zones begin to develop, tourist infrastructure is being created, processes are underway to inform the population about the country's tourism opportunities, cruise liners are being built (Avanesyan, 2012). In Azerbaijan in the 1990s, a significant outflow of holidaymakers was observed. At present, tourism is beginning to develop rapidly and gain momentum. The progressive development of the tourism sector in this country of the Caspian region is largely facilitated by the unique nature and specificity of local attractions: mosques, temples, ancient settlements. Azerbaijan is proud of its world-class resort in Amburan, which already today has high tourist attractiveness in terms of pricing and quality of guest services. The construction of a modern tourist complex in the village of Nardaran, which will have not only upscale buildings but also modern comfortable cottages, has begun. The Sea Breeze resort is generally compatible with the famous hotels in Miami. Countries such as Russia, Kazakhstan, and Turkmenistan are also making a significant impact on the sustainable development of tourism in this region, launching a large number of investment projects in this area, including resort areas, tourist complexes, construction of cruise ships, etc. Next, let us consider the regions of the Caspian region that are part of the Russian Federation: Astrakhan Region, Republic of Kalmykia and Republic of Dagestan. The Astrakhan Region is distinguished by its favorable geographical position, significant economic, resource, recreational, scientific, technical, and infrastructural potential. The economic and geographical position of the Astrakhan Region is characterized by the fact that it occupies the southern part of the East European Plain in the territory of the Caspian Lowland, the Volga-Akhtuba floodplain and the Volga delta, which allows developing a variety of types of tourism within its area (Arutyunyan and Soloviev, 2019;). The Volga River crosses the Astrakhan Region, giving great opportunities for the development of cruise tourism in the region (Sorokin D.E., and all, 2017). Cruises are dispatched from moorings in the Golden Zaton. Astrakhan river cruise tourism has great development prospects. At the present stage of its development, one can state the fact that the potential of cruise tourism is significantly underutilized. The Astrakhan Region has a convenient geographical position - any delta site is already advantageous as it has both river and sea communication. In addition, it is obvious that any cruise is access to completely different foreign markets. The tourist and recreational potential of the territory, natural, cultural, historical, and socio-economic factors determine the spatial characteristics of tourism. The biological resources of the region are also of great economic importance.

Ecological, educational and scientific tourism is provided by a wide variety of rare and relict species of fauna and flora, and by the presence of numerous archaeological and historical landmarks. It is known that cultural 
heritage increases the tourist potential of the region. The restoration of monuments of architecture and urban planning allowed expanding guided tourism in the historical part of the city of Astrakhan. A separate area of guided tourism is children's cultural tourism (Adelman and Bunakov, 2016). Event tourism is associated with visiting iconic cultural, historical, social, professional, archaeological events: a gastronomic festival of national cuisine, an art festival, fisherman's day, reconstruction of a historic city, etc. can be considered an innovative form of tourism in the Astrakhan Region. Water cruises along the Volga and the Caspian Sea provide diversification of the tourist product of the Astrakhan Region. The Republic of Kalmykia has tremendous tourism potential that needs to be developed. The historical, cultural and natural heritage of the Kalmyk people, ancient national traditions, folk crafts - all this contributes to the development of almost all types of tourism - sightseeing, business, educational, medical (folk medicine), environmental, youth, cultural, educational, religious and educational, as well as hunting and fishing. Today, the unlimited opportunities of the unique nature of the Republic of Kalmykia are used for tourism purposes only on a very modest scale.

Possessing a variety of flora and fauna, convenient location, numerous ancient mounds, having favorable tourist opportunities, Kalmykia has not yet been represented in the market of tourist services.

In general, the development of tourism in the Republic of Kalmykia is constrained by the following factors: - general socio-economic instability, leading to an abrupt fall in demand, a sharp polarization of supply and demand to the detriment of the range and quality of services, the degradation of all forms of social tourism;

- lack of necessary funding for the implementation of tourism development programs in the Republic of Kalmykia;

- lack of an information-analytical system and mechanisms for collecting regular statistics in tourism and, as a result, the absence of serious analytical market research and marketing programs for the development of tourism in the Republic;

- inconsistency of the tourism infrastructure with world and European standards in all respects, primarily in terms of the quality and safety of the services provided;

- insufficiently developed tourism infrastructure in the area of the Republic;

- lack of a unified advertising policy among the subjects of tourism activities to create the image of the region, insufficient advertising of the national (republican) tourist product.

In the Republic of Dagestan, tourism activity began to develop over the past 2-3 years. Cultural resources belong to a high category (Derbent) but are almost unknown in the world. Nevertheless, the Republic of Dagestan has a high potential for the development of the tourist and recreational complex. Using unique climatic and historicalcultural opportunities, a powerful complex of tourist and recreational facilities can be created in the Republic. According to experts, the industry potential (recreational capacity) is more than 2 million tourists a year. In the future, until 2025, it is planned to develop the Sulak and Makhachkala seaside, the Magaramkent section of the Derbent seaside and mountain territories (Akhtynsky, Tabasaransky, Gunibsky, Khunzakhsky, Laksky and other districts), which will allow organizing a variety of sports (Pisarevsky, 2012). The main barrier to the development of tourism in Dagestan is the negative image that is emerging due to the unsafe situation in the region. The close proximity of the Chechen Republic is a source of a constant influx of refugees into the region. As reported, the cities of Dagestan periodically suffer from terrorist acts. Other barriers to the development of tourism in Dagestan are similar to those in Astrakhan, which is located on the northern border: undeveloped transport and tourist infrastructure, low level of service that does not meet the international standards. The negative image of Dagestan is also affected by the lack of an effective marketing strategy in the region. First of all, it is necessary to overcome the barrier associated with the airport capacity, given that tourism should become an economic driver in the coming years. It is planned to make some investments in the region to develop tourism (for example, the development of Novokayakent (sea coast), but these planned investments are not enough to ensure the planned increase in the tourist flow. Cruise tourism in the Caspian region is one of the fast-growing segments of the international tourism market, which has great resource potential due to the presence of the Caspian water area linking these countries, the ever-increasing demand and high sustainability that can be achieved in this type of tourism. The increase in demand for cruise tourism is characterized by environmental components of sustainable 
development, a balance of socio-economic interests while maintaining the principles of cross-border cooperation (Lomova et al., 2019; Almeida et al., 2019; Jafarpour et al., 2019; Aleksandrova et al., 2017; Nikolaeva et al., 2019; Maulana et al., 2019). In this regard, the initial model for the study of sustainable development of cruise tourism in the Caspian region can be represented as follows (Fig. 3). However, in order to organize cruise tourism in the Caspian Sea, it is necessary to solve a number of issues - the creation of a company or companies that will organize the whole process, the construction of special cruise liners, the creation of the necessary modern infrastructure, the construction of parking and marinas for yachts, the preparation of beaches, the formation of a single recognizable tourist package, as well as the training of specialists. (Karabsheva, 2018).

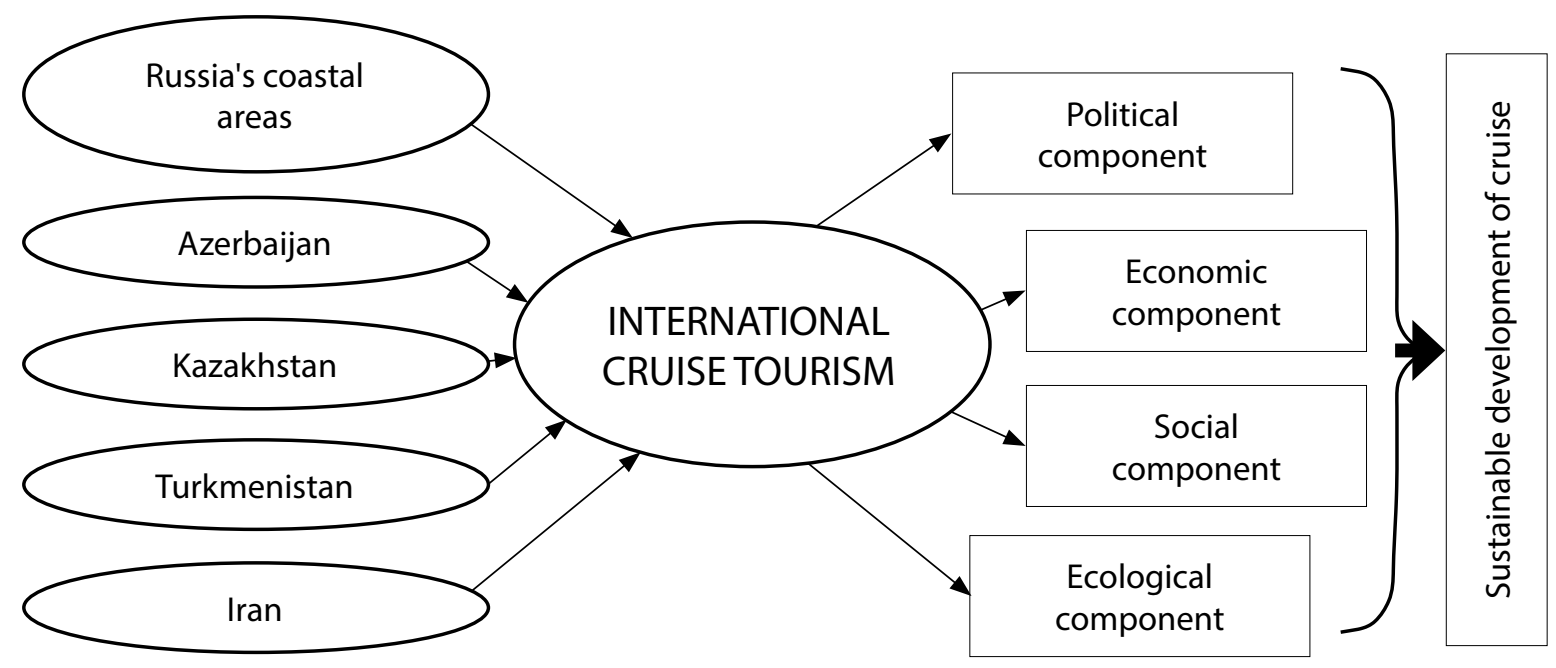

Figure 3. Sustainable development model of cruise tourism in the Caspian region

Source: authors' research

There are many tasks, but they are all solvable. Their solution can open a whole new page in the development of tourism and open for tourists the Caspian Fairy-Tale. Despite the lack of a direct exit from the Caspian Sea to the world ocean and a short exit to other seas, tourists arriving in one of the Caspian countries could make a short tour of the Caspian Sea. There are also all the conditions for the development of international cruise tourism from the ports of the Caspian countries (Ovcharov, 2008; Paiano et al., 2020). Currently, there is a qualitative increase in international sea cruises in this region. By analogy with hotels, cruise ships are assigned appropriate stars depending on a number of certain criteria, such as: rigging and tourist infrastructure of the vessel, quality of passenger cabin conditions, level and quality of food onboard, availability of entertainment programs and a range of additional services onboard the liner, etc. For the development of international cruise tourism in the Caspian countries, there is currently an opportunity to use a system of channels that will enable cruise ships from the Mediterranean and Black Seas to go to the Caspian Sea and visit the Caspian countries during the navigation season. This will ensure a long, but fascinating journey, while covering more countries. In December 2017, a memorandum on cooperation with Russia in the field of international tourism was signed in the capital of Azerbaijan, Baku. The main emphasis is on the use of "Peter the Great" cruise ship. A set of cruise routes has already been developed, involving the ports of Astrakhan and almost all the ports of the Caspian countries. (Frolova et al., 2019).

Among the main segments that influence the development of cruise tourism in the Caspian region are the following:

1. Sea cruises (cruise liners, cruise ferries, cruise yachts);

2. River cruises;

3. Expedition cruises.

Cabins on sea cruise liners should vary in interior, range of services, and, accordingly, price category. Ferries, as a type of sea cruise ship, due to their economical category, will also be quite popular in international cruises, 
as they are also multi-deck sea vessels (http://www.unep.fr). River cruises are those made within countries with access to the waters of the Caspian Sea.

Expedition cruises can be sea or river, the main purpose being to visit remote and inaccessible places in the countries of the Caspian region while maintaining an acceptable level of comfort and quality of tourist services. Based on the foregoing, the initial research model (Fig. 2) should be presented as follows (Fig. 4):

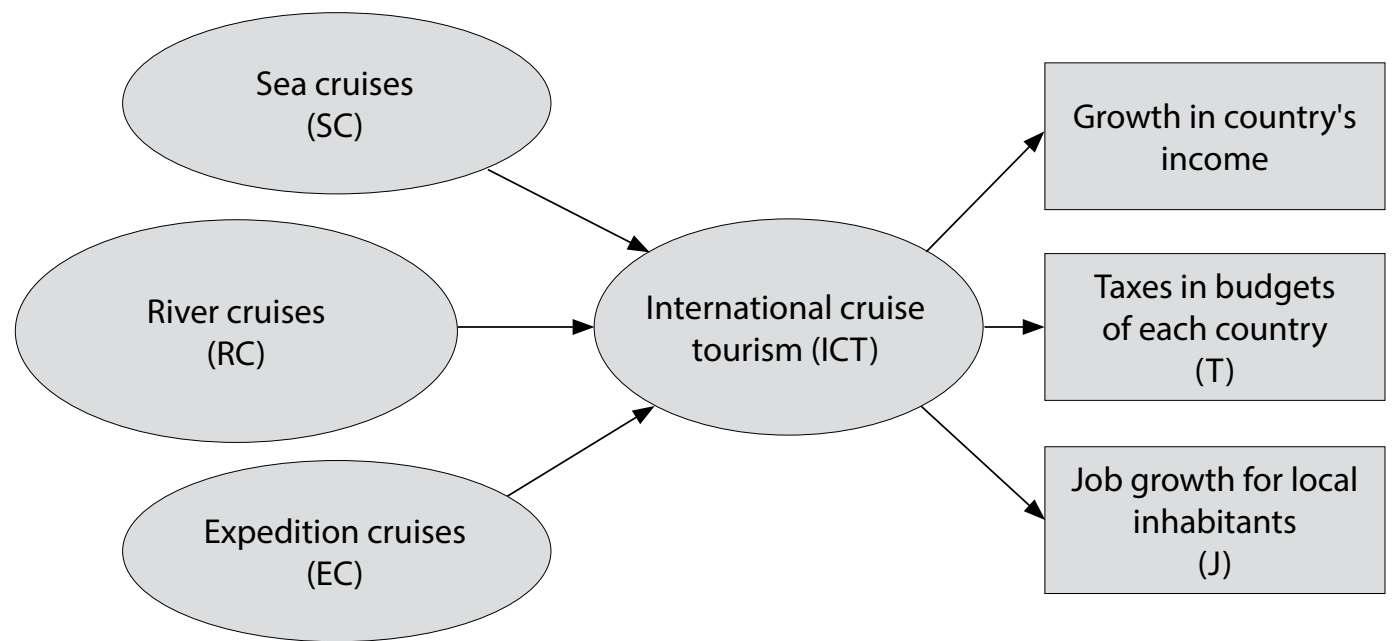

Figure 4. Development model of cruise tourism in the Caspian region

Source: authors' research

In order to identify how effective and sustainable each of the cruise tourism destinations for each of the countries of the Caspian region is, it is necessary to use the principles and conditions of optimization modeling, reflecting the relationship between generic (indicators of socio-economic development) and explicit variables (criteria) (Kashirskaya et al., 2018).

Generic variables are displayed in the model as ovals, and explicit variables - as rectangles. According to the optimization modeling algorithm, the following formula can be applied:

$$
R_{I C T}=\alpha_{0}+\alpha_{1} R_{S C}+\alpha_{2} R_{R C}+\alpha_{3} R_{E C}+r . d_{\cdot I C T}
$$

where: $R_{S C}, R_{R C}, R_{E C}$ - generic variables, $\alpha_{1}, \alpha_{2}, \alpha_{3}$ - coefficients reflecting the strength and direction of relations between generic variables, $\alpha_{0}-$ free term, $r . d_{\cdot I C T}-$ random deviate.

Under these conditions, the development model of international cruise tourism of a sustainable type will have the following form:

$$
\left\{\begin{array}{l}
Y_{\text {Psc }}=G_{0 s c}+G_{1 s c} R_{I C T}+\text { r.d. } \\
Y_{\text {Prc }}=G_{0 r c}+G_{1 r c} R_{I C T}+\text { r. d.rc } \\
Y_{\text {ec }}=G_{0 e c}+G_{1 e c} R_{I C T}+\text { r.d.ec }
\end{array}\right.
$$

where: $Y_{P s c}, Y_{P r c}, Y_{e c}-$ explicit variables, $G_{1 s c}, G_{1 r c}, G_{1 e c}-$ demand factors, $G_{0 s c}, G_{0 r c}, G_{0 e c}-$ free terms, r.d.sc $, r . d_{\cdot r c}, r . d_{. e c}-$ random deviate.

The construction of the optimization model was based on the statistical base of the Association of Sea Trade Ports (www.morport.com), which is reflected in Table (Rassohina T.V. 2013; Seselkin A.I., 2013). 
Table 1. Internal consistency of cruise tourism segments reflected in the model

\begin{tabular}{|l|c|c|c|c|}
\hline \multicolumn{1}{|c|}{ Segments } & Cronbach's alpha, $\alpha_{\text {Cr }}$ & Dillon and Goldstein's, $\rho_{\text {DGol }}$ & Eigenvalue, $G_{1}$ & Eigenvalue, $G_{2}$ \\
\hline Sea cruises (SC) & 0.88 & 0.94 & 4.15 & 0.75 \\
\hline River cruises (RC) & 0.83 & 0.91 & 1.82 & 0.28 \\
\hline Expedition cruises (EC) & 0.71 & 0.90 & 1.87 & 0.29 \\
\hline
\end{tabular}

All three criteria for consistency meet the necessary conditions $\left(\alpha_{\mathrm{Cr}}>0.7, \rho_{\mathrm{DGol}}>0.7, \mathrm{G}_{1 \pm}>1, \mathrm{G}_{2}<1\right)$.

The obtained values confirm the fact about the correctness and applicability of this optimization model. Moreover, this model shows that sea cruises in the Caspian Sea are most optimal from the perspective the theory of sustainable tourism development, in relation to other segments of international cruise tourism.(Kruzhalin V.I., and all,2014) This is also confirmed by the performance of the main segments of international cruises in the Caspian region (Table 2).

Table 2. Profitability of the activities in segments that influence the sustainable development of international cruise tourism in the Caspian region

\begin{tabular}{|l|c|c|c|c|c|c|c|c|c|}
\hline & 2009 & 2010 & 2011 & 2012 & 2013 & 2014 & 2015 & 2016 & 2017 \\
\hline Sea cruises & $19 \%$ & $21 \%$ & $14 \%$ & $22 \%$ & $25 \%$ & $27 \%$ & $26 \%$ & $13 \%$ & $17 \%$ \\
\hline River cruises & $11 \%$ & $-8 \%$ & $7 \%$ & $-8 \%$ & $-7 \%$ & $12 \%$ & $11 \%$ & $14 \%$ & $13 \%$ \\
\hline Expedition cruises & $-4 \%$ & $-11 \%$ & $-18 \%$ & $-23 \%$ & $-21 \%$ & $-17 \%$ & $-22 \%$ & $-19 \%$ & $-27 \%$ \\
\hline
\end{tabular}

Using the results, built on the average actual growth indices of socio-economic indicators for each country of the Caspian region, it becomes possible to focus on the development of international cruise tourism, taking into account the priority of its segments.

\section{Conclusions}

Thus, one can conclude that by developing sustainable tourism, the countries of the Caspian region are developing international cooperation based on the principles of common interests. At the same time, international cooperation acts as one of the types of political cooperation, which logically supplements the theory of sustainable development, since it is based not only on socio-economic and political parameters but also assumes the equality of the parties, the responsibility of partners in tourism services and in the development of tourism in general. The article explored approaches to the development of sustainable tourism in the region. A model for the development of international tourism in the Caspian region is proposed. Among the main segments that influence the development of cruise tourism in the region are marked sea cruises, river and expeditionary.

\section{References}

Adelman B.M., \& Bunakov O.A. (2016). The evolution of sustainable tourism management concepts in the regions. Competitiveness in the Global World: Economics, Science, Technology, 1, 191-194.

Akhmetshin, E. M., Plaskova, N. S., Iusupova, I. I., Prodanova, N. A., Leontyev, A. N., \& Vasilev, V. L. (2019). Dataset for determining rational taxation value with incompatible criteria of economic efficiency and equity. Data in Brief, 26 https://doi:10.1016/j. dib.2019.104532

Aleksandrova, T. N., Arustamyan, K. M., \& Romanenko, S. A. (2017). The mathematical analysis methods application in estimation of the international practice of copper-zinc and pyritic-polymetallic ores selective flotation. Obogashchenie Rud, 2017(5), 21-27. https:// doi:10.17580/or.2017.05.04

Almeida, M. V. D. A., Silva, E. M. D., Gomes, N. Â., Nunes, L. A. O., \& Curi, W. F. (2019). Environmental quality of campina grande landfill based on technical and operational aspects. [Qualidade ambiental do aterro sanitário de campina grande com base em aspectos técnicos e operacionais] Periodico Tche Quimica, 16(32), 77-86. 
Arutyunyan S. A., \& Soloviev N.V. (2019). International cruises as a factor in the sustainable development of tourism in the Caspian region. Economics and Management: Problems, Solutions 1(2 (85)), 115 - 122.

Avanesyan M.M. (2012). The formation of the Caspian recreational area. Modern research and innovation. Number 2.

Chernysheva, A. M., Trofimova, A. A., Kalygina, V. V., \& Bulatenko, M. A. (2019). Factors of developing international retail chain brands in the regions of the russian federation. Space and Culture, India, 6(5), 115-123. https://doi:10.20896/SACI.V6I5.479

Chkalova, O., Efremova, M., Lezhnin, V., Polukhina, A., Sheresheva, M. 2019. Innovative mechanism for local tourism system management: a case study, Entrepreneurship and Sustainability Issues 6(4): 2052-2067. http://doi.org/10.9770/jesi.2019.6.4(35)

Dunets, A. N., Vakhrushev, I. B., Sukhova, M. G., Sokolov, M. S., Utkina, K. M., Shichiyakh, R. A. (2019b). Selection of strategic priorities for sustainable development of tourism in a mountain region: concentration of tourist infrastructure or nature-oriented tourism. Entrepreneurship and Sustainability Issues, 7(2), 1217-1229. https://doi.org/10.9770/jesi.2019.7.2(29)

Dunets, A., Muhamedieva, A., Sycheva, I., Perepechkina, E., Vakhrushev, I., \& Kulchytskiy, A. (2019a). Spatial tourism planning: Using the model of functional and planning complexes. Journal of Environmental Management and Tourism, 10(4), 711-719. https:// doi:10.14505/jemt.v10.4(36).01

Fedulova, I., Ivanova, V., Atyukova, O., \& Nosov, V. (2019). Inclusive education as a basis for sustainable development of society. Journal of Social Studies Education Research, 10(3), 118-135.

Frolova, I., Voronkova, O., Alekhina, N., Kovaleva, I., Prodanova, N., \& Kashirskaya, L. (2019). Corruption as an obstacle to sustainable development: A regional example. Entrepreneurship and Sustainability Issues, 7(1), 674-689. https://doi:10.9770/jesi.2019.7.1(48)

Glotko, A., Sycheva, I., Petrova, L., Vorozheykina, T., Tolmachev, A., \& Islamutdinova, D. (2019). Environmental problems of processing industry in the agro-industrial complex of the region. Journal of Environmental Management and Tourism, 10(5), 974-983. https:// doi:10.14505/jemt.v10.5(37).04

Goryushkina, N. E., Gaifutdinova, T. V., Logvina, E. V., Redkin, A. G., Kudryavtsev, V. V., \& Shol, Y. N. (2019). Basic principles of tourist services market segmentation. International Journal of Economics and Business Administration, 7(2), 139-150.

Ivanova, V., Poltarykhin, A., Szromnik, A., \& Anichkina, O. (2019). Economic policy for country’s digitalization: A case study. Entrepreneurship and Sustainability Issues, 7(1), 649-661. https://doi:10.9770/jesi.2019.7.1(46)

Jafarpour, H., Moghadasi, J., Khormali, A., Petrakov, D. G., \& Ashena, R. (2019). Increasing the stimulation efficiency of heterogeneous carbonate reservoirs by developing a multi-bached acid system. Journal of Petroleum Science and Engineering, 172, 50-59. https:// doi:10.1016/j.petrol.2018.09.034

Karabsheva M.R. (2018). Methods of system analysis in the study of transport systems. Bulletin of Eurasian science, 10(6), 15.

Kashirskaya L. V., Karabasheva M. R., Zykina M. A. (2018). The method of scenario planning costs for transportation services. Problems of Economics and legal practice, 2, 65-70.

Kashirskaya, L., Voronkova, O., Sitnov, A., Shichiyakh, R., Kudinova, M., \& Sycheva, I. (2019). Rural development through the formation of zonal agro-ecological clusters. Journal of Environmental Management and Tourism, 10(3), 651-659. https://doi:10.14505/jemt. v10.3(35). 19

Kolupaev A.A., Redkin A.G., Voinova N.E., Karabasheva M.R., Rzayev A.Ya.O., Makhanova T.A. (2018). Main attributes of tourism transportation infrastructure formation. International Journal of Mechanical Engineering and Technology, 9(12), $1185-1197$.

Korableva, O. N., Kalimullina, O. V., Zaytseva, A. A., \& Larionov, A. I. (2018). Elaboration of database for the subject domain of innovation and economic growth potential. Paper presented at the Proceedings of the 31 st International Business Information Management Association Conference, IBIMA 2018: Innovation Management and Education Excellence through Vision 2020, $6065-6073$.

Korchevenkov, S., \& Aleksandrova, T. (2018). Investigation of the influence a morphologic characteristics of the noble metal particles on gravity efficiency devices. Paper presented at the International Multidisciplinary Scientific GeoConference Surveying Geology and Mining Ecology Management, SGEM, 18(1.4) 99-104. https://doi:10.5593/sgem2018/1.4/S04.013

Kruzhalin V.I., Mironenko N.S., Siegern-Korn N.V., \& Shabalina N.V. (2014). The geography of tourism. M.: Federal Agency for Tourism. P. 336.

Lomova, L. A., Voronkova, O. Y., Aleshko, R. A., Goneev, I. A., Avdeev, Y., \& Sochnikova, I. Y. (2019). Ecological and economic consequences of water pollution. International Journal of Engineering and Advanced Technology, 9(1), 7056-7062. https://doi:10.35940/ ijeat.A1925.109119 
Luzina, T. V., Dudareva, E. A., Akhmetshin, E. M., Prodanova, N. A., Berdova, Y. S., \& Emaletdinova, G. E. (2019). International legal format for trans regionalisation of trade and economic partnership within BRICS in global development. Space and Culture, India, 7(3), 76-85. https://doi:10.20896/saci.v7i3.508

Making Tourism More Sustainable: A Guide for Policy Makers, WTO\&UNEP, 2005. http://www.unep.fr/pc/tourism/library/home.htm Map of the Astrakhan region. M.: Ministry of Natural Resources and Ecology of the Russian Federation. 2019. http://www.mnr.gov.ru Maulana, M., Hanova, Y., Waruwu, A., \& Ratama, P. E. (2019). Simplified method for prediction of settlement in bamboo piles-reinforced peat under embankment. Journal of Applied Engineering Science, 17(1), 35-42.

Nikolaeva, N., Romashev, A., Aleksandrova, T. (2019). Degree evaluation of grinding on fractional composition at destruction of polymineral raw materials. Paper presented at the IMPC 2018 - 29th International Mineral Processing Congress, 474-480.

Ovcharov A.O. (2008). Tourist complex in Russia: trends and risks. Economic issues, 1, 108-119.

Paiano A., Crovella T., \& Lagioia G. (2020). Managing sustainable practices in cruise tourism: the assessment of carbon footprint and waste of water and beverage packing. Tourism Management, 77.

Pavlyshyn, L., Voronkova, O., Yakutina, M., \& Tesleva, E. (2019). Ethical problems concerning dialectic interaction of culture and civilization. Journal of Social Studies Education Research, 10(3), 236-248.

Pisarevsky E.L. (2012). Tourism development strategy as a key area of state regulation of tourism in the Russian Federation. Quarterly scientific readings. M: Logos, 35-45.

Porokhin A.V., \& Urban N.A. (2015). Modern scientific approaches to determining the essence of economic sustainability. Economic sciences (08.00.00). 11, 600-604.

Prodanova, N. A., Smolentsev, V. M., Norkina, A. N., Shukshina, Y. A., \& Polyanskaya, O. A. (2017). Formation of system of internal control and features its functioning in the innovative development of industrial enterprises. International Journal of Applied Business and Economic Research, 15(13), 179-189.

Prodanova, N. A., Trofimova, L. B., Bashina, O. E., Kachkova, O. E., Ilienkova, N. D., \& Polyanskaya, T. A. (2019). Approaches for obtaining audit evidence at fair value measurement. International Journal of Economics and Business Administration, 7(3), 279-292.

Prokhorova, M. P., Prodanova, N. A., Reznichenko, S. M., Vasiliev, V. P., \& Kireev, V. S. (2016). Innovation performance and its influence on enterprise economic efficiency in the market. International Journal of Economics and Financial Issues, 6 (8Special Issue), 78-83.

Rassokhina T.V., \& Seselkin A.I. (2013). Problems of assessing the tourism development system in tourist destinations. University Herald. 1, 48-53.

Rosland M. (2001). Sustainable communities are a sustainable planet. Wave, 4(29), 34-43.

ROSTURISM [Electronic resource]. Development of cruise tourism in the area of special attention: http://russiatourism.ru/news/10946/

Shevyakova, A., Munsh, E., Arystan, M. 2019. Information support for the development of tourism for the diversification of the economy of Kazakhstan. Insights into Regional Development 1(2): 138-154. https://doi.org/10.9770/ird.2019.1.2(5)

Singgalen, Y.A., Sasongko, G., Wiloso, P.G. 2019. Community participation in regional tourism development: a case study in North Halmahera Regency - Indonesia. Insights into Regional Development, 1(4), 318-332. https://doi.org/10.9770/ird.2019.1.4(3)

Sorokin D.E., Sharafutdinov V.N., \& Onishchenko E.V. (2017). On the problems of tourism development strategy in the regions of Russia (on the example of the Krasnodar Territory and the resort city of Sochi). The economy of the region, 3. 764-776.

Tarman, B. (2016). Innovation and Education. Research in Social Sciences and Technology, 1(1). Retrieved from http://ressat.org/index. $\mathrm{php} /$ ressat/article/view/3

Vasilchenko A.O. (2018). Analysis of factors of sustainable development of the region in the field of tourism and hospitality (on the example of the Brest region). Young scientist. Number, 18, 297-306.

Voronkova, O. Y., Iakimova, L. A., Frolova, I. I., Shafranskaya, C. I., Kamolov, S. G., \& Prodanova, N. A. (2019). Sustainable development of territories based on the integrated use of industry, resource and environmental potential. International Journal of Economics and Business Administration, 7(2), 151-163. 
Yang, J., Černevičiūtè, 2017. Cultural and Creative industries (CCI) and sustainable development: China's cultural industries clusters. Entrepreneurship and Sustainability Issues, 5(2), 231-242. http://doi.org/10.9770/jesi.2017.5.2(6)

Zakorin N.D. (2009). Investment development of the tourism potential of the region. St. Petersburg: D.A.R.K. - 196 p.

Zhylankozova, A. 2018. Towards the Silk Road economic zone initiative: historical perspective. Entrepreneurship and Sustainability Issues, 6(2), 548-557. http://doi.org/10.9770/jesi.2018.6.2(6)

\section{Robert Hernández MARTÍNEZ}

Ph.D. Universidad Iberoamericana, Mexico City, Position in Faculty: Coordinator of the Actuarial Science Program - Department of Phisycs and Mathematics, Faculty: Universidad Iberoamericana, Mexico City.

ORCID ID: https://orcid.org/0000-0001-8542-765X

\section{Svetlana Aikovna ARUTYUNYAN}

Candidate of Economic Science, Assistant Professor, docent Chair of Management, Astrakhan State University. Research interests: tourism, sustainable tourism, regional economy, management, financial management.

ORCID ID: https://orcid.org/0000-0003-4662-0072

\section{Malvina Rasulovna KARABASHEVA}

Docent of the accounting, analysis and audit department of the Financial University under the Government of the Russian Federation, Moscow, Russian Federation.Research interests - accounting expertise, state financial control, budgetary establishments, departmental interaction, efficiency of activity.

ORCID ID: https://orcid.org/0000-0003-3728-9867

\section{Aigul Iklasovna YESTURLIYEVA}

Candidate of Economics, Assistant Professor of the Department «Economic security». Research interests- Socio-economic development.

ORCID ID: https://orcid.org/0000-0002-8374-1706

Register for an ORCID ID:

https://orcid.org/register

This work is licensed under the Creative Commons Attribution International License (CC BY)

http://creativecommons.org/licenses/by/4.0/ 